\section{Resistance to papaya ringspot virus in Cucumis metuliferus and its relationship to resistance to watermelon mosaic virus 1}

\section{R. Provvldentl and D. Gonsalves}

ABSTRACT: In cross and backcross populations of PI 292190 - an accession of Cucumts motuliferis (Naud.) May. resistant to papaye ringspot virus (PRVS)-with a susceptible line (ACC. 2459) of the same species, re sistance to this virus was conferred by a single dominant gene. Clones of $F_{2}$ and testcross plants inoculated with PASV or watermeton mosaic virus 1 (WMV-1) reacted Identically, suggesting that the factor for resistance to PASV is closely linked to $W / m v$, or may be the same factor. PRSV and WMV-1 are known to be closely related serologically. Acc. 2459 of C. matulifens ('homed cucumber' or 'jelly melon') is a valuable host for the propagation of isolates of PRSV.

PAPAYA RINGSPOT VIRUS (PRVS) occurs commonly wherever papaya (Carica papaya L.) is cultivated ${ }^{8}$. This potyvirus is transmitted efficiently by several species of aphids ${ }^{4}$ and usually spreads rapidly with destructive consequences ${ }^{3,5.6 .10 .12 .13}$. PRSV also is able to infect several cucurbit species and some isolates incite symptoms resembling those caused by watermelon mosaic virus 1 (WMV-1). Although a close serological relationship between PRSV and WMV-1 has been demonstrated ${ }^{29}$, WMV-1 does not infect papaya.

Recently, we found that genotypes of $\mathrm{Cu}$ cumis metuliferus (Naud.) Mey., C. melo L., C. sativus L., Lagenaria siceraria (Mol.) Standl., and Cucurbita ecuadorensis Cuttler and Whitaker, which are resistant to WMV-1, also are resistant to PRVS isolates from $\mathrm{Ha}$ waii and Florida (unpublished data). Previously, Provvidenti and Robinson ${ }^{7}$ reported that in C. metuliferus (commonly known as the 'horned cucumber' or 'jelly melon') resistance to WMV-1 is governed by a single dominant gene $(\mathrm{Wmv})$. The purpose of this investigation was to elucidate the mode of inheritance of resistance to PRSV in this species and to determine whether the factors conferring resistance to PRSV and WMV-1 are linked.

\section{Materials and Methods}

The genetic background of the C. metuliferus germplasm utilized in this study was

The authors are members of the Department of Plant Pathology, New York State Agricultural Experiment Station, Cornell University, Geneva, New York 14456.

(C) 1982, American Genetic Association. similar to that previously used to determine the inheritance of resistance to WMV-17. Plants of Acc. 2459, susceptible to PRSV and WMV-1, were crossed with those of PI 292190 , a line resistant to both viruses. Uniformity in germination was achieved by placing seed on moist blotters in plastic boxes, which were initially incubated at $5^{\circ} \mathrm{C}$ for $3-5$ days and then to $30^{\circ} \mathrm{C}$. Plants of $F_{1}, F_{2}$, and those of reciprocal backcross populations were mechanically inoculated when they had reached the two-leaf stage. To assure infection in all the susceptible genotypes, plants were reinoculated at the four-leaf stage. Inoculum was derived from Cucurbita pepo L. cv. Seneca Zucchini, or plants of Acc. 2459 systemically infected with the Hawaiian isolate PRSV-HA ${ }^{2}$. The same hosts were used as sources of inoculum for isolate NY69-49 of WMV-1 ${ }^{7}$. Stock cultures of PRSV-HA and two other isolates PRSV-HB (Hawaii) and PRSV-Fla (Florida) were maintained in $C$ papaya cv. Solo.

Clones of $F_{2}$ and testcross plants were used to determine linkage between PRSV and WMV-1 resistance factors. Thus, each plant of these populations was separately tested with PRSV or WMV-1.

Enzyme-linked immunosorbent assay (ELISA) was employed in determining infectivity of PRSV or WMV-1 in inoculated plants ${ }^{2}$. An antiserum to PRSV-HA had been prepared by Gonsalves and Ishii ${ }^{2}$, and that to WMV-1 was supplied by D. E. Purcifull [University of Florida]. The work was conducted in an insect-free greenhouse maintained at $27^{\circ} \mathrm{C}$.

\section{Results}

Plants of PI 292190 inoculated with PRSV-HA were free of local and systemic infection. Those of Acc. 2459, after an incubation period of $7-10$ days, developed veinal chlorosis, mottle, reduction of leaf size and short internodes. Severely affected plants tended to wilt and died prematurely. Plants of Acc. 2459 responded with a very prominent mosaic to infection caused by PRSV-HB, and

Table I. Segregation in $\mathrm{F}_{1}, \mathrm{~F}_{2}$, and reciprocal backcross populations of Cucumis metuliferus for resistance to papaya ringspot virus

\begin{tabular}{|c|c|c|c|c|}
\hline \multirow[b]{2}{*}{ Populations } & \multicolumn{2}{|c|}{ No. plants } & \multirow{2}{*}{$\begin{array}{c}\text { Expected } \\
\text { ratio }\end{array}$} & \multirow{2}{*}{$\begin{array}{c}\text { Goodness- } \\
\text { of-fit } \\
(P) \\
\end{array}$} \\
\hline & resistant & susceptible & & \\
\hline PI 292190 & 75 & 0 & & \\
\hline Acc. 2459 & 0 & 70 & & \\
\hline $\begin{array}{c}\text { (Acc. } 2459 \times \mathrm{PI} \\
292190) \mathrm{F}_{1}\end{array}$ & 43 & 0 & & \\
\hline $\begin{array}{c}\text { (Acc. } 2459 \times \mathrm{PI} \\
292190) \mathrm{F}_{2}\end{array}$ & 194 & 68 & $3: 1$ & 0.72 \\
\hline $\begin{array}{l}\text { (Acc. } 2459 \times \mathrm{PI} \\
292190 \text { ) } \mathrm{F}_{1} \times \mathrm{PI} \\
292190\end{array}$ & 135 & 0 & & \\
\hline $\begin{array}{l}\text { (Acc. } 2459 \times \text { PI } \\
29219 \text { ) F } \times \text { Acc. } \\
2459\end{array}$ & 71 & 62 & $1: 1$ & 0.45 \\
\hline
\end{tabular}

with a mild or moderate mottle to PRSV-Fla. Conversely, both PRSV-HB and PRSV-Fla incited only a few systemic chlorotic spots on Seneca Zucchini squash and after a longer incubation period (15-20 days). Isolate PRSV-HA caused more prominent symptoms in this same host and the incubation period was 12-15 days.

Plants of $F_{1}$ behaved as the resistant parent and no virus infection was detected in inoculated and uninoculated leaves. Plants of the $\mathrm{F}_{2}$ generation segregated in a ratio of 3 resistant to 1 susceptible. Resistant plants were free of local and systemic infection, whereas susceptible plants exhibited symptoms identical to that of the susceptible parent. The progeny of the backcross to the resistant parent was all resistant. Plants of the testcross segregated in a ratio of nearly 1 resistant to 1 susceptible. From the data presented in Table I, it is evident that resistance is conferred by a single, completely dominant gene.

The segregation of clones of $\mathrm{F}_{2}$ and testcross populations, which had been inoculated with PRSV or WMV-1, is reported in Table II. Plants that were resistant to PRSV also were resistant to WMV-1; conversely, those that were susceptible to PRSV also were susceptible to WMV-1. The segregation pattern for both populations approximated the expected ratios.

\section{Discussion}

This study has revealed that resistance to PRSV in C. metuliferus is monogenically dominant. Data from clones of $F_{2}$ and testcross plants indicate a close linkage between the factor for resistance to PRSV and $W m v$, the gene for resistance to WMV $-1^{7}$. However, no gene symbol has been assigned to the factor for PRVS resistance because it is possible that Wmv may be responsible for the resistance to both viruses. PRSV and WMV-1 share a number of common features: 1] they belong to the potyvirus group ${ }^{8} ; 2$ ) they are very closely related serologically 2,$8 ; 3$ ) they share a common, although not identical host range ${ }^{8,13}$; and 4) in several species, plants resistant to 
Table II. Reaction of clones of $F_{2}$ and testcross populations of Cucumis metuliferus to papaya ringspot virus (PRSV) and watermelon mosaic virus 1 (WMV-1)

\begin{tabular}{|c|c|c|c|c|c|}
\hline \multirow[b]{2}{*}{ Populations } & \multirow[b]{2}{*}{ Virus } & \multicolumn{2}{|c|}{ No. plants } & \multirow{2}{*}{$\begin{array}{l}\text { Expected } \\
\text { ratio }\end{array}$} & \multirow{2}{*}{$\begin{array}{c}\text { Goodness- } \\
\text { of-fit } \\
\text { (P) }\end{array}$} \\
\hline & & resistant $^{\star}$ & susceptible $^{\dagger}$ & & \\
\hline (Acc. $2459 \times$ PI & PRSV & 63 & 23 & $3: 1$ & 0.69 \\
\hline $292190 \mid F_{2}$ & WMV-1 & 63 & 23 & & \\
\hline (Acc. $2459 \times \mathrm{PI}$ & PRSV & 39 & 34 & $1: 1$ & 0.57 \\
\hline $\begin{array}{l}292190\} F_{1} \times \\
\text { Acc. } 2459\end{array}$ & WMV-1 & 39 & 34 & & \\
\hline
\end{tabular}

* Plants resistant to PRSV also were resistant to WMV-1

t Plants susceptible to PRSV also were susceptible to WMV-1

WMV-1 also are resistant to PRSV. A few years ago, Schroeder and Provvidenti ${ }^{11}$ demonstrated that in Pisum sativum L. resistance to bean yellow mosaic virus (BYMV) and to watermelon mosaic virus 2 (WMV-2) is conditioned by the same gene $(\mathrm{mo})$. Both BYMV and WMV-2 are potyviruses, have common hosts, and are serologically related ${ }^{\mathbf{1}}$. Further work on the comparison of RNA nucleotide sequence homologies of PRSV and WMV-1 will eventually determine how closely related these two viruses are, and whether they should be considered strains of the same virus.

Wang et al. ${ }^{13}$ reported that PI 292190 was susceptible to an isolate of PRSV from Taiwan. The difference in reaction could be attributed to a different strain of the virus, mixture of viruses, or a mislabeled seed lot. The sensitivity of C. Metuliferus Acc. 2459 to infection with isolates of PRVS, makes this a valuable line for propagation of this virus.

\section{References}

1. BRANDES. I Identifizierung von gestreckten pflanzenpathologenen viren auf morphologischer Grundlage. Mitteilungen Biol. Bundesunstalt Land Forstwirtschaften 100:1-130. 1964.

2. Gonsalves, D. and M. IshiI. Purification and serology of papaya ringspot virus Phytopatho$\log y$ 70:1028-1032. 1980.

3. IsHII, M. Observations on the spread of papaya ringspot virus in Hawaii. Pl. Dis. Reptr. 56:

4. JENSEN. D. D. Papaya ringspol virus and its insect vector relationships. Phytopathology 39: 212-220. 1949.

5. LASTRA, R. and E. Quintero. Papaya apical necrosis, a new disease associated with a rhabdovirus. PI. Dis. Reptr. 65:439-440. 1981.

6. LIMA, I. A. A. and M. N. S. Gomes Identificacao de 'papaya ringspot virus' em Fortaleza, Ceara. Fitossanidade 1:56-59. 1975.

7. Provvidenti, R. and R. W. RoBinson. Inheritance of resistance to watermelon mosaic virus 1 in Cucumıs metuliferus. J. Hered. 68.56-57. 1977.

8. PURCIFULL, D. E. Papaya ringspot virus, no. 84 In Description of Plant Viruses. Comm. Mycol. Inst. Assoc. Appl. Biol., Kew, Surrey, England. 1972.

9. $\longrightarrow$ and E. HIEBERT. Serological distinction of watermelon mosaic virus isolates. Phytopathology 69:112-116. 1979

10. SANCHEZ de LuQUE, C. and G. MarTinez LOPE3. Reconocimiento del vinus de la mancha anular de la papaya (Carica papaya L.) en $\mathrm{Co}$ lombia. Revistu ICA 11:205-220. 1976.

11. SChroeder, $W$. T. and R. Provvidenti. A common gene for resistance to bean yellow mosalic virus and watermolon mosaic virus 2 . in Pisum sativum. Phytopathology 61:846-848. 1971.

12. SuREKA, S. K., K. MATHUR, and D. D. SHUKLA Virus diseases of Papaya (Carica papoya) in Udaipur. Indian I. Mycol. Pl. Path. 7:115-121. 1977.

13. WANG, H. L, C. C. WANG, R. J. ChIU, and M. SUN. A preliminary study of papaya ringspol virus in Taiwan. Pl. Protect. Bull. 20:133-140. 1978. 331-337. 1972
The Journal of Heredity 73:240-242. 1982.

\section{Endosperm balance numbers among New Guinea-Indonesian Impatiens species}

Toru Arisumi

ABSTRACT: The results of crosses among various plant accessions of Impations speciess from the New Gulnea-Indonestan area support the endosperm batance number (EBN) hypothesis. Whith few exceptions, crosses among plants with equal EBN's succeoded and those between unequal EBN's failed. Existing cross data indicate that the present collection of New Gulnea-Indonesian impatiens is comprised of standard (2EBN) and tetraploid (4EBN) specles.

THE ENDOSPERM BALANCE NUMBER (EBN) hypothesis was proposed by Johnston et al. ${ }^{9}$ to explain endosperm development in interploidyintraspecific and interspecific crosses. To test this hypothesis, a species to be used as a standard is arbitrarily assigned an EBN. Other species are assigned EBN's on the basis of their crossing behavior with the standard species. According to this hypothesis it is the EBN's that determine the effective ploidy in the endosperm, and for successful endosperm development the EBN's must be in a maternal:paternal ratio of $2: 1$. Johnston and Hanneman ${ }^{10}$ used results of crosses among tuber-bearing Solanum species to support the EBN hypothesis. The authors 9,10 noted that other interactions also are important in determining endosperm development and that the 2:1 EBN ratio was a necessary but not sufficient condition for a successful cross.

The purpose of this study was to test the validity and predictive value of the EBN hypothesis using results of breeding experiments with $\mathrm{Im}$ patiens species from the New Guinea-Indonesian area. This group seemed to be good material for these tests because: 1) it was comprised of diverse species showing cytological as well as morphological differences; 2 ) the breeding behavior of most of the species and the colchicine-induced polyploids of their hybrids was known; and 3) some new plant accessions were available for testing the predictive value of the EBN's.

\section{Materials and Methods}

The species and hybrids used in the present tests and some that had been studied in the past are listed and described in Table I. The EBN's of these species and the references from which the EBN determinations were obtained are also listed in Table I with the eight new species listed at the end. Seven of these species were from the New Guinea-Indonesian area. One species, M28

The author is research plant geneticist with the Florist and Nursery Crops Laboratory, Horticultural Science Institute, USDA, ARS, Beltsville, MD 20705 He thanks Dr. Gilbert McCollum for his helpful suggestions and for reviewing the manuscript. 